Journal of Animal and Veterinary Advances 9 (24): 3005-3007, 2010

ISSN: $1680-5593$

(C) Medwell Journals, 2010

\title{
The Polymorphism of Prolactin Gene in Native Chicken Zabol Region
}

\author{
Masoud Alipanah, Kamal Shojaian and Hussein Khani Bandani \\ Department of Animal Science, University of Zabol, Post Box 98615-538, Zabol, Iran
}

\begin{abstract}
The aim of this study was to determine genetic polymorphism of prolactin gene for native chickens Zabol. Avian prolactin hormone located in chromosome No: 2. It is a polypeptide that it molecular weight is 21700-26000 Dalton and effective in increasing broodiness and commonly results in regression of the ovary. In this study, blood samples were collected from 30 native chickens randomly and DNA was extracted. The PCR was used to amplify $439 \mathrm{bp}$ fragments for prolactin gene locus. The amplified fragment was digested with Alu I enzyme. Allele frequencies of $\mathrm{T}$ and $\mathrm{C}$ prolactin hormone gene for native chickens were $0 / 67,0 / 33$, respectively. Genotype frequencies TT, CT, CC in herd were $53 / 33,26 / 67$ and $20 / 00 \%$, respectively. The results show that PCR-RFLP method is proper for genotype determination of prolactin gene chicken studies.
\end{abstract}

Key words: Prolactin gene, polymorphism, PCR-RFLP, native chicken, amplified, Iran

\section{INTRODUCTION}

The native chicken PRL genomic sequence has $6,163 \mathrm{bp}$ long. The five exons are $28,182,108,180$ and $192 \mathrm{bp}$ long. The four introns are 1,520, 408, 1,348 and 1,909 bp long (AU and Leany, 2002).

Physiologically, it has been well established that prolactin in poultry play an important role in the onset of incubation of hens. Increased plasma prolactin concentration is associated with the occurrence of broodiness.

During incubation, prolactin mRNA reaches its highest level which infers that prolactin is important in the maintenance of broodiness.

Egg laying pattern in domestic hen is characteristic to the breed of birds. Genetically superior birds takes fewer pauses compared to native breed of birds developed for dual purpose, resistant to diseases and adverse climatic variables as backyard poultry in rural areas (Reddy et al., 2006).

It has been reported that most of sequence polymorphisms in the chicken PRL gene occur in 5 flanking region, 3 flanking region and coding region of the signal peptide (Wong et al., 1991; Zhou et al., 2001; Cui et al., 2006).

Therefore, polymorphisms in the promoter region especially those that result in changes of promoter binding sites, most likely influence mRNA expression thus influencing hen incubation behavior and egg production. Polymorphisms of 5 flanking region of chicken Prolactin
(cPRL) gene were examined in several populations of Chinese native Yuehuang, Taihe Silkie and White Leghorn Layer chickens. Four Single Nucleotide Polymorphisms (SNPs) were identified at position$2425(\mathrm{C} / \mathrm{T}),-2215(\mathrm{~T} / \mathrm{C}),-2063(\mathrm{G} / \mathrm{A})$ and $-1967(\mathrm{~A} / \mathrm{G})$. A 24 bp indel (insertion or deletion) and a polyA length polymorphism were also identified.

For the $24 \mathrm{bp}$ I ndel locus, three enotypes (AA, AB and $\mathrm{BB}$ ) were found in Yuehuang chickens while o nly two genotypes were detected in Taihe Silkie (AB and $\mathrm{BB}$ ) and Leghorn chickens (AA and BB).

The genotype frequencies of $\mathrm{AA}, \mathrm{AB}$ and $\mathrm{BB}$ were significantly different among the three breeds. For the polyA locus, although three genotypes $(\mathrm{CC}, \mathrm{Cd}$ and $\mathrm{DD})$ were found, only one genotype $(\mathrm{CC})$ was detected in White Leghorn chickens while two or three genotypes were observed in Chinese native chickens.

The results show that chickens with genotype $\mathrm{AB}$ of $24 \mathrm{bp}$ indel locus which are of the highest incidence of broodiness had the highest cPRL mRNA levels providing the possibility that this polymorphic site might be related to the broodiness in chickens via modulating the transcriptional level of cPRL gene (Liang et al., 2006). Broodiness is observed in most breeds of domestic fowl with the exception of the White Leghorn which has undergone long-term artificial selection to minimize phenotypic expression of this behavior (Romanov et al., 2002). The purpose of this study was to estimate the allelic frequencies at the prolactin gene in native chicken of Zabol region.

Corresponding Author: Masoud Alipanah, Department of Animal Science, University of Zabol, Post Box 98615-538, Zabol, Iran 


\section{MATERIALS AND METHODS}

A total of 100 samples were genotyped for prolactin gene. The birds used for this study was a Iranian native breed in Zabol region. The chicken produce almost $<100$ egg year ${ }^{-1}$ and exhibits broodiness.

Genomic DNA extraction venous blood was collected from the wing vein of each individual with EDTA as an anticoagulant. Blood samples were stored at $-30^{\circ} \mathrm{C}$ till the time for DNA extraction.

Genomic DNA was extracted from the whole blood by the conventional phenol/chloroform extraction method or with a DNA extraction kit (Gene Fanavaran Iran). The prolactin genotypes were analysed using the PCR-RFLP method. PCR products were amplified using primers as previously described (Cui et al., 2006):

\section{FA: forward 5'-AGA GGCAGCCCA GGCATT TTA-C-3',} Reverse 5 - CCT GGG TCT GGT TTG GAA ATT G -3'

Cycles applied were denaturation $-94^{\circ} \mathrm{C} / 5 \mathrm{~min}$ followed by 35 cycles $94^{\circ} \mathrm{C} / 30 \mathrm{sec}$, annealing $60^{\circ} \mathrm{C} / 30$ sec, extension $72^{\circ} \mathrm{C} / 30 \mathrm{sec}$ and final extension $72^{\circ} \mathrm{C} / 5$ min. PCR Conditions: $2.5 \mu \mathrm{L} 10 \times \mathrm{PCR}$ buffer $(15 \mathrm{mM}$ $\mathrm{MgCl}_{2}$ ) $1.5 \mu \mathrm{L}$ dNTP-mix ( $2 \mathrm{Mm}$ each), $1.5 \mu \mathrm{L}$ of primer (100 pmol $\mu \mathrm{L}^{-1}$ each), $0.5 \mathrm{u}$ Taq DNA polymerase (genefanavaran, Iran) Amplified DNA was digested with Alu I enzyme. Digestion products were separated electrophoretically in 3\% (w/v) agarose gel. Frequencies of distribution of alleles within the herds were compared with $\chi^{2}$-test.

\section{RESULTS AND DISCUSSION}

The electrophoretic profiles fragment of prolactin gene obtained from primer pair 5FA are shown in Fig. 1. For the polymorphism, three genotypes and two alleles were distinguishable according to their restriction fragment lengths: 160, 144, 81 and $54 \mathrm{bp}$ (C allele) and 304, 81 and $54 \mathrm{bp}$ ( $\mathrm{T}$ allele). Genotypes and alleles of the prolactin gene are shown in Fig. 2.

In this breed the frequencies of alleles were as follows; $\mathrm{T}=0.67, \mathrm{C}=0.33$. The frequencies of $\mathrm{TT}, \mathrm{TC}$ and $\mathrm{CC}$ genotypes were $0.53,0.27$ and 0.20 , respectively. Frequency of prolactin allele A obtained in this study are similar to those reported by Jiang et al. (2005) for white rock ( 0.65 and 0.35 , respectively) no the results was differ for Whit Leghorn and Yangshan (1.00 and 0.00 and 0.05 and 0.95 , respectively).

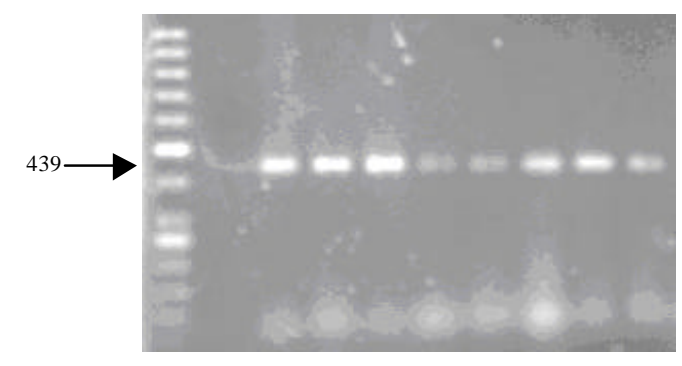

Fig. 1: Gel picture of prolactin fragment amplified by primer pair 5FA before digestion

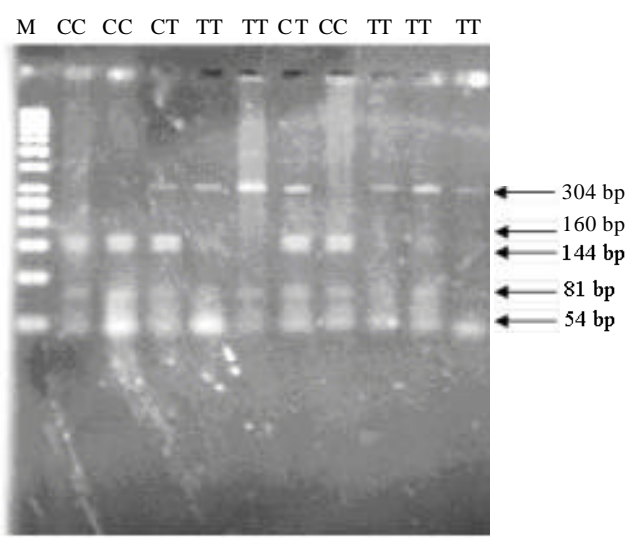

Fig. 2: Restriction analysis of cPRL $439 \mathrm{bp}$ PCR products digested with Alu I by $3 \% \mathrm{w} / \mathrm{v}$ agarose gel electrophoresis stained with ethidium bromide. $\mathrm{CC}$ genotype $=160,144,81$ and $54 \mathrm{bp} ; \mathrm{CT}$ genotype $=$ restriction fragments of $304,160,144$, 81 and $54 \mathrm{bp}$; TT genotype $=$ restriction fragment of 304,81 and $54 \mathrm{bp}$

\section{CONCLUSION}

Prolactin one the pituitary hormones, regulates important physiological functions in animals also have effect on nesting behavior (broodiness) in bird (Elkins et al., 2000). Comparison among chicken breeds show that selected breeds for egg production as leghorn is seldom broodiness however native chicken breeds have current broodiness in order to maintain normal reproduction. Therefore, if decided to select native chicken for egg production, we can use of polymorphism prolactin gene for reduction broodiness.

\section{REFERENCES}

AU, W.L. and F.C. Leany, 2002. Rapid communication: Complete nucleotide sequence of the chicken prolactin gene. J. Anim. Sci., 80: 1381-1381. 
Cui, J.X., H.L. Du, Y. Liang, X.M. Deny, N. Li and X.Q. Zhany, 2006. Association of polymorphism in the promoter Region of Chicken prolactin with egg production. Poult. Sci., 85: 26-31.

Elkins, P.A., H.W. Christinger, Y. Sandowiski, E. Sakal, A. Gertler, A.M. de Vos and A.A. Kossiakoff, 2000. Ternary complex between placenta lactogen and the exteracellular domain of the prolactin receptor. Nat. Struct. Biol., 7: 808-815.

Jiang, R.S., G.Y. Xu, X.Q. Zhang and N. Yang, 2005. Association of polymorphism for prolactin and prolactin receptor genes with broody traits in chickens. Poult. Sci., 84: 839-845.

Liang, Y., J. Cui, G. Yang, F.C.C. Leung and X. Zhang, 2006. Polymorphism of 5 flanking region of chicken prolactin gene. Domestic Anim. Endocrinol., 30: $1-160$.
Reddy, G.J., C.G. David and S.S. Raju, 2006. Chemical control of prolactin secretion and Its effects on pause days egg production and steroid hormone concentration in girirani birds. J. Poult. Sci., 5: 685-692.

Romanov, M.N., R.T. Talbot, P.W. Wilson and P.J. Sharp, 2002. Genetic control of incubation behavior in the domestic hen. Poultry Sci., 81: 928-931.

Wong, E.A., N.H. Ferrin, J.L. Silaby and M.E. El Halawani, 1991. Cloning of a Turkey PRL cDNA: Expression of PRL hormone through the reproductive cycle of the domestic turkey (Meleagris gallopavo). Gen. Comp. Endocrinol., 83: 18-26.

Zhou, M., X.Q. Zhang, Z.D. Shi and Y.C. Cao, 2001. Cloning and sequencing of prolactin gene cDNA in three chicken breeds. Yi Chuan Xue Bao, 28: 614-620. 